\title{
Ultrastructural observations on gamogonic stages of Goussia subepithelialis (Apicomplexa, Coccidia) from common carp Cyprinus carpio
}

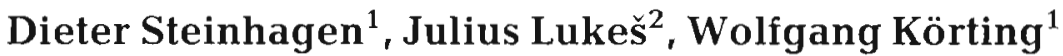 \\ ${ }^{1}$ Fish Disease Research Unit, School of Veterinary Medicine, Bünteweg 17, D-3000 Hannover 71, Federal Republic of Germany \\ ${ }^{2}$ Institute of Parasitology, Czechoslovak Academy of Sciences, Branišovská 31, 37005 České Budějovice, Czechoslovakia
}

\begin{abstract}
Gamogonic stages of Goussia subepithelialis were observed in the gut of carp from South Bohemian and North German ponds during March and April 1988 and 1989. Large microgamonts (21 to 44 by 16 to $18 \mu \mathrm{m}, \mathrm{n}=20$ ) with highly invaginated surfaces developed within epithelial cells. The microgamonts gave rise to numerous biflagellate microgametes (24 to 43 per plane in cross sections). Developing macrogamonts were located in the apical region of intestinal epithelial cells in a parasitophorous vacuole with scattered intravacuolar vesicles and intravacuolar blebs formed by the parasitophorous membrane. Mature macrogamonts were 14 to 19 by 11 to $15 \mu \mathrm{m}$ in size and formed large electron-dense bodies with electron-lucent spaces. In other respects macrogametogenesis was similar to that of other piscine eimerian species.
\end{abstract}

\section{INTRODUCTION}

Goussia (syn. Eimeria) subepithelialis (Moroff and Fiebiger, 1905) is parasitic in the intestinal tract of common carp Cyprinus carpio causing 'nodular coccidiosis'. Infections were found in early spring only. Gamonts, sporogonic stages and oocysts were observed in posterior regions of the intestine mainly - often forming white nodules. The meronts, gamonts and sporulated oocysts were described by early workers (Moroff \& Fiebiger 1905, Ziesche 1914, Schäperclaus 1943, Pellérdy \& Molnár 1968), while the course of infection and a detailed description of morphological development were presented by Marinček (1973).

In this paper ultrastructural observations on gamogonic developmental stages of Goussia subepithelialis are presented.

\section{MATERIALS AND METHODS}

From May to September 1988 and from March to May 1989, in a survey of parasites of common carp Cyprinus carpio from South Bohemia (Ceské Budějovice, Czechoslovakia) and North Germany (Celle, Lower Saxony), a total of 32 out of 94 fish examined contained oocysts and developmental stages of Goussia subepithelialis. Intestinal scrapings were observed by light microscopy as wet mounts. Microphotographs and measurements for identification of the species were taken from fresh sporocysts and oocysts. For light microscopy toluidine blue, semithin sections were examined and photographed. For electron microscopy small pieces of infected tissue were fixed either in $2.5 \%$ glutaraldehyde in $0.1 \mathrm{M}$ cacodylate buffer, $\mathrm{pH}$ 7.2 at $4{ }^{\circ} \mathrm{C}$, postfixed in $1 \% \mathrm{OsO}_{4}$ for $1 \mathrm{~h}$ in the same buffer and en bloc stained with $0.5 \%$ uranyl acetate, or fixed in $2 \% \mathrm{OsO}_{4}$ in $0.1 \mathrm{M}$ cacodylate buffer, $\mathrm{pH} 7.2$ for $1 \mathrm{~h}$ at $4^{\circ} \mathrm{C}$. After dehydration in graded series of ethanol, the tissue was embedded in Epon-Araldite or Spurr's resin. Thin sections were cut with glass knives on LKB Ultrotome III and Reichert Ultracut E microtomes. Sections were stained with uranyl acetate and lead citrate and examined in Philips 420 and Zeiss EM 10 A electron microscopes.

\section{RESULTS}

Carp of different age groups harboured pinhead sized white patches in the intestinal wall. These were found to contain masses of developmental stages (in 


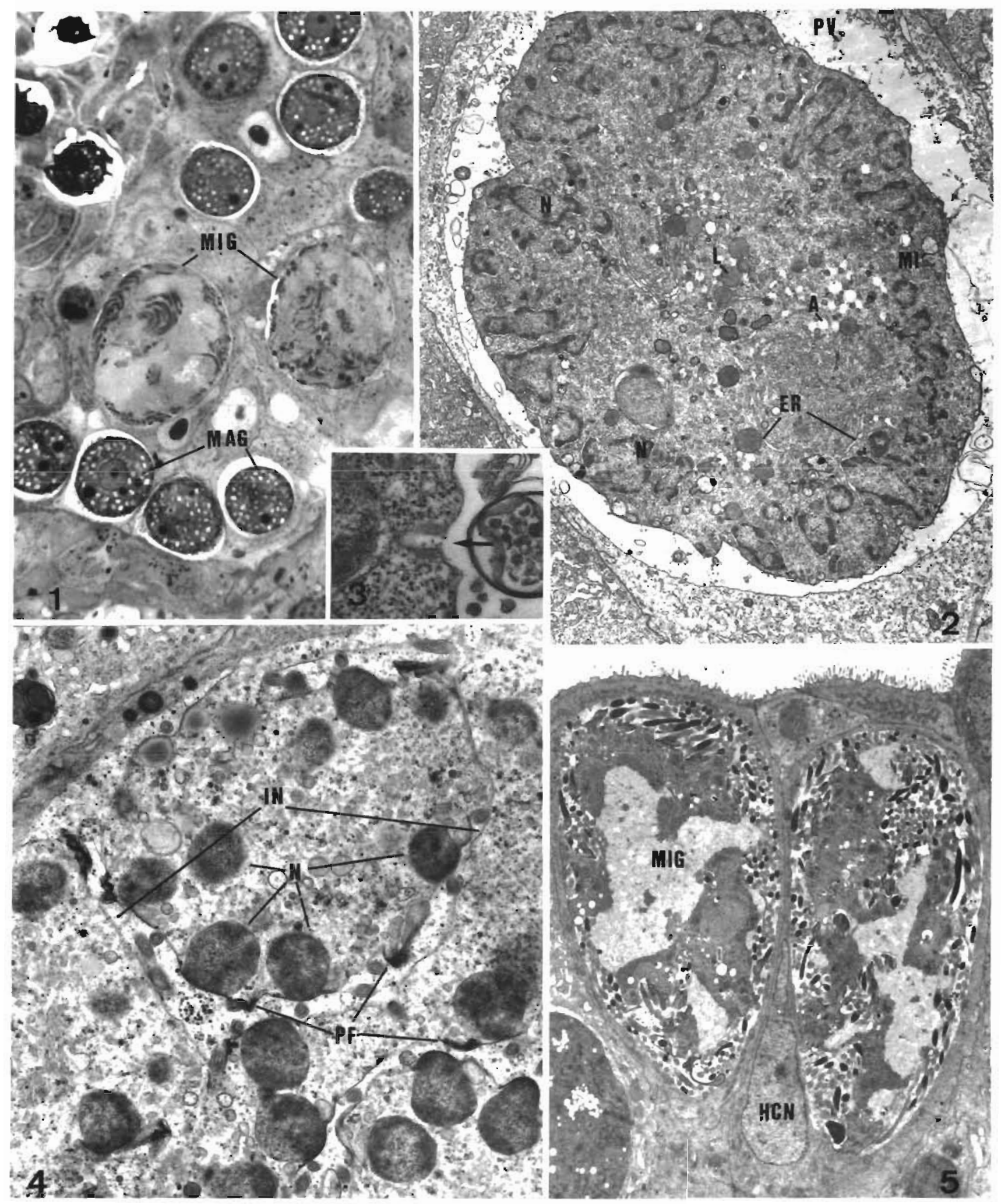

Figs 1 to 5 Goussia subepithelialis parasitic in Cyprinus carpio. Fig. 1. A cluster of microgamonts (MIG) with microgametes and macrogamonts (MAG) in intestinal tissue of carp Semithın section; toluidine blue $\times 870$ Fig. 2. Multinucleate microgamont with penpherally arranged nuclei ( $N$ ), mitochondria (MI), endoplasmic reticula (ER), lipid (L) and amylopectin (A) inclusions, and parasitophorous vacuole (PV); $\times 4500$. Fig. 3. Microgamont, surface membrane with micropore (arrow); $\times 34000$. Fig. 4 . Matunng microgamont with deep invaginations (IN) of the surface membrane, penpherally arranged nuclei ( $N$ ), and developing perforatoria (PF); $\times 7200$. Fig 5. Mature microgamonts (MIG) with numerous microgametes in epithelial intestinal cells. HCN: host cell nucleus; $\times 2400$ 
Table 1. Goussia subepithelialis. Cell dimensions (in $\mu \mathrm{m}$ )

\begin{tabular}{|c|c|c|c|}
\hline Oocyst diam & Sporocysts length $\times$ width & Sporozoites length $\times$ width & Source \\
\hline $\begin{array}{l}18-21 \\
18(17-19\}\end{array}$ & $\begin{array}{l}15 \times 8 \\
14.3(13-15) \times 6.3(5-7)\end{array}$ & $\begin{array}{l}15-16 \times 1.5-2.0 \\
13(12-14) \times 3(2.5-4)\end{array}$ & $\begin{array}{l}\text { Moroff \& Fiebiger }(1905)^{a} \\
\text { This study }\end{array}$ \\
\hline $\begin{array}{l}{ }^{a} \text { No. parasite } \\
{ }^{b} \text { No. parasite }\end{array}$ & $\begin{array}{l}\text { ed not given } \\
\text { ed }=20\end{array}$ & & \\
\hline
\end{tabular}

the period March through April) and oocysts (April to September) of Goussia subepithelialis. The species diagnosis was based on measurements and the morphological features of fresh oocysts (Table 1). Stages of gametogenesis were found in histological sections (Fig. 1) and in thin sections from material sampled during March and April.

\section{Microgamonts and microgametes}

Young microgamonts contained numerous small nuclei with peripherally arranged heterochromatin. In the cytoplasm, cisternae of granular endoplasmic reticulum (ER), free ribosomes and mitochondria (MI) were abundant (Fig. 2), lipid inclusions (L) and electron-lucent vesicles were also present. The cells were lined by a single membrane with micropores (Fig. 3). In the parasitophorous vacuole (PV) numerous intravacuolar vesicles were scattered. In maturing microgamonts, deep invaginations of the cell surface occurred, with the nuclei located beneath the cell's surface (Fig. 4). The cell membrane near the nuclei formed dense thickenings, i.e. perforatorium anlagen (PF, Figs. 4 and 6). Mature microgamonts were round to oval in cross section, 25 to 44 by 16 to $30 \mu$ m (mean 33.3 \pm 5.27 by $21.2 \pm 4.1 \mu \mathrm{m}, \mathrm{n}=20$ ) in size (Figs. 1 and 5 ). The cell surface showed deep invaginations with developing microgametes emerging from the microgamont. (Figs. 1, 4, 5 and 7) and among originating microgametes intravacuolar vesicles could be discerned. In cross sections 24 to 43 microgametes were counted per plane $(n=20)$. The microgametes exhibited an apical, dense protrusion (perforatorium, Figs. 4,6 and 7), 2 flagella (Fig. 8), a mitochondrion (Figs. 7 , 8 and 9), and a dense elongate nucleus, up to $7.2 \mu \mathrm{m}$ in length. The mitochondrium was situated anteriorly from the nucleus (Figs. 8 and 9) which was the last structure of the microgamete to be separated from the microgamont. A residual portion of the nucleus was left behind in the microgamont (Figs. 7 and 9). In cross sections of the microgamete several microtubules were visible in close association with nucleus and mitochondrion, the number and configuration of microtubules varied per section plane (Fig. 10).

\section{Macrogamonts and macrogametes}

Developing macrogamonts were located in the apical region of intestinal epithelial cells in a parasitophorous vacuole with scattered intravacuolar vesicles (Figs. 12 and 13). The parasitophorous vacuole membrane formed intravacuolar blebs (Fig. 13). Macrogamonts in all stages of development were bound by a single membrane with few micropores. The parasites had a large nucleus often in a central position and with a prominent nucleolus, abundant free ribosomes, and cisternae of the ER. In early developmental stages, the cisternae were arranged concentrically around the nucleus and had contact with the nuclear envelope (Fig. 11). Electron-lucent amylopectin granules, lipid inclusions, electron-dense membranebound vesicles of various size, and mitochondria were scattered in the cytoplasm but tended to concentrate near the limiting membrane (Fig. 11). With advancing development the number of amylopectin inclusions increased (Figs. 12 and 13). Mature macrogamonts had numerous large amylopectin inclusions and numerous membrane-bound electron-dense vesicles which varied in size and appearance: dense bodies with electron-pale spaces (Fig. 12), small bodies of high density (Fig. 13), and bodies of medium densities (Figs. 12 and 13). The cytoplasm appeared denser due to an increased number of free ribosomes. The ER cisternae beneath the limiting membrane were present in most areas. Mature macrogamonts measured 14 to 19 by 11 to $15 \mu \mathrm{m}$ (mean $=16.3$ \pm 1.30 by $13.3 \pm 1.35 \mu \mathrm{m}, \mathrm{n}=20$ ). The relative abundance of macrogamonts to microgamonts was about 5:1 in thin sections.

Fertilization of macrogamonts was not observed. Stages considered to be zygotes were spherical in shape, had a central nucleus, numerous large amylopectin inclusions and large electron-dense membranebound bodies. The cell was limited by a wall, consisting of two membranes with electron dense material deposited between these membranes (Fig. 14).

\section{DISCUSSION}

Gamogonic developmental stages of Goussia subepithelialis were found in the intestine of carp from 


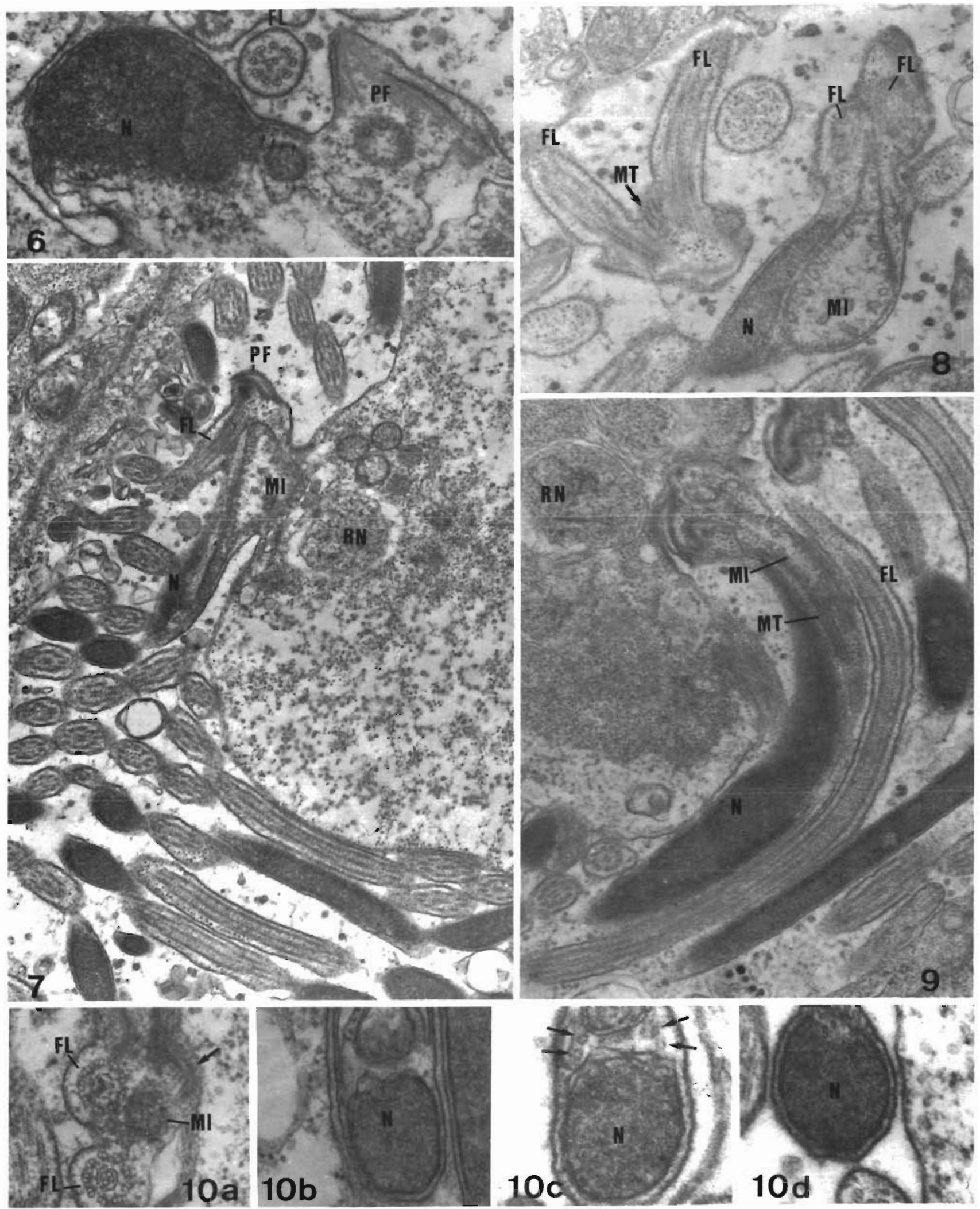

Figs 6 to 10. Goussia subepithelialis parasitic in Cyprinus carpio. Formation of microgametes. Fig 6 . Emerging nucleus (N) associated with microtubuli (arrows), and formation of a perforatorium (PF). Flagellum (FL) also included; $\times 35000$. Fig. 7 Microgamete with perforatorium (PF), flagellum (FL), mitochondrion (MI) and nucleus (N) emerging from the microgamont and leaving a residual nucleus $(\mathrm{RN})$ behind. Note cross sections of numerous microgametes; $\times 14500$. Figs. 8 and 9 . Longitudinal sections of microgametes, showing flagella (FL), microtubules (MT), mitochondrion (MI), and nucleus ( $N, R N)$; $\times 22700$ and 18000 respectively. Fig. 10. Cross section of microgametes at different body regions, showing the arrangement of nucleus, mitochondrion and microtubules (arrows in c). Inner sheet of microtubules visible in (a). Magnifications are: $(a, b) \times 45000$; (c) $\times 90000 ;(d) \times 60000$ 

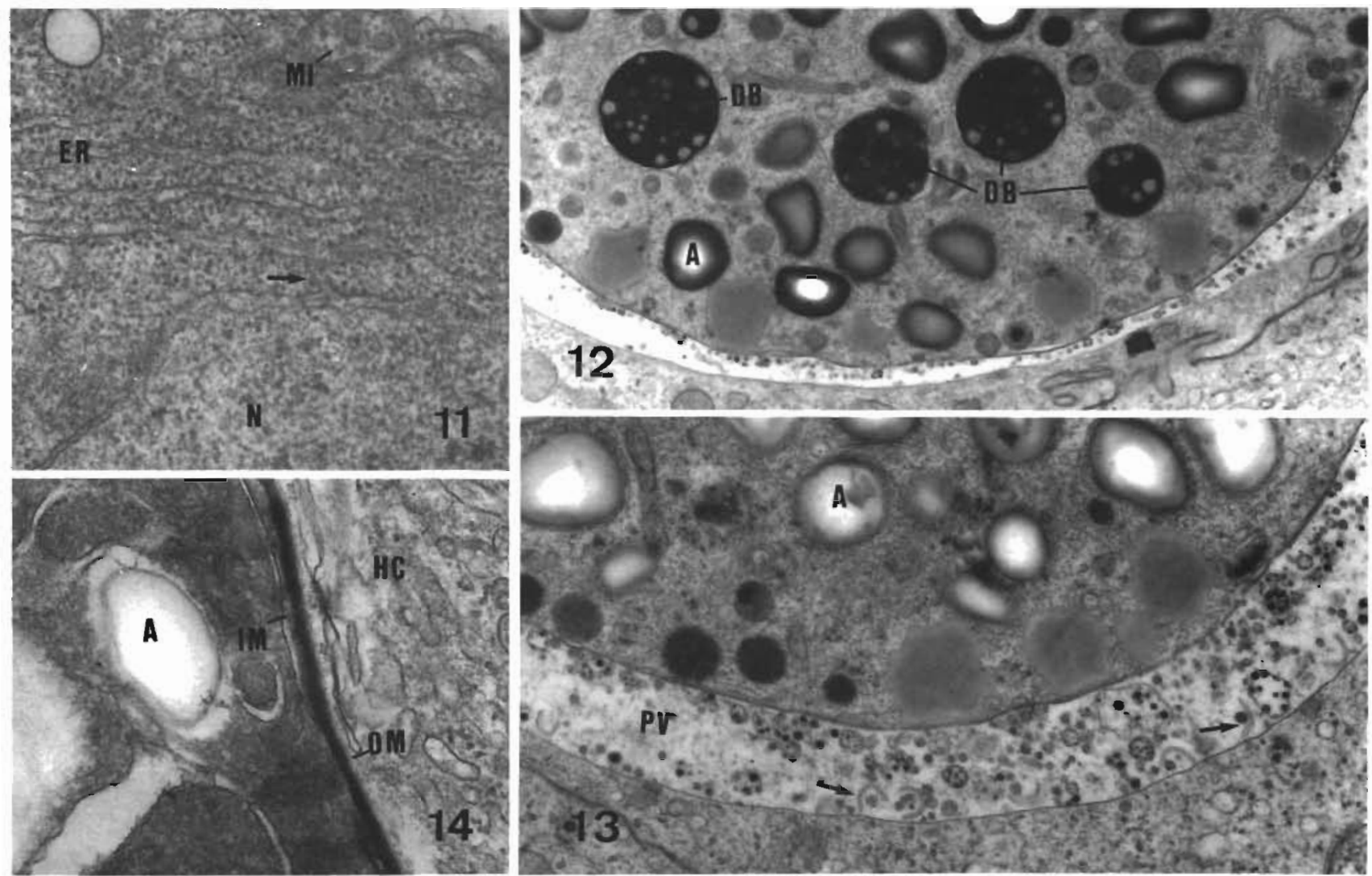

Figs. 11 to 14. Goussia subepithelialis parasitic in Cyprinus carpio. Macrogamogenesis. Fig. 11. Early macrogamont, the nuclear envelope has contact with the ER (arrow). Nucleus $(\mathrm{N})$, and mitochondria (MI) also indicated; $\times 36000$. Fig. 12 . Advanced macrogamont with amylopectin inclusions (A) and electron-dense membrane-bound bodies, small bodies of high density and dense bodies $(\mathrm{DB})$ with electron-pale spaces; $\times 7980$. Fig. 13. Advanced macrogamont with ER cisternae underlying the body wall. Numerous intravacuolar vesicles and portions of parasitophorous vacuole membrane (arrows) are scattered in the space of the parasitophorous vacuole (PV); $\times 13200$. Fig. 14. Zygote with bilayered body wall (inner membrane: IM, outer membrane: $\mathrm{OM})$ and accumulation of electron-dense material between 2 the layers and host cell $(\mathrm{HC}) ; \times 35500$

South Bohemian and North German ponds during early spring only The biology of $G$. subepithelialis in experimental infections induced by oral administration of oocysts to carp was studied by Marinček (1973). These laboratory-infected carp were examined over a period of about $60 \mathrm{~d}$, and Marinček (1973) found different stages of merogony but no further developmental stages. Therefore she suggested that $G$. subepithelialis had a seasonal developmental cycle: with carp becoming infected during summer, and gamogonic and sporogonic development taking place after the winter when the water temperature in the ponds increased (Marincek 1973). Our observations confirm this pattern of seasonal development.

Data on the ultrastructure of eimerian parasites from piscine hosts, as reported in the literature (Paterson \& Desser 1981a, b, Hawkins et al. 1983a, b, Desser \& Li 1984, Paperna et al. 1986) and presented in this communication indicate a basic pattern of development similar to stages of Eimeria species of terrestrian hosts
(Chobotar \& Scholtyseck 1982). In Goussia subepithelialis sexual stages were found mainly in epithelial cells of the intestinal mucosa but they often accumulated in large aggregates which latter may have invaded the lamina propria (Moroff \& Fiebiger 1905, Marinček 1973)

Only Goussia iroquoina microgametocytes and microgametes were studied in detail (Paterson \& Desser 1981a), and brief information were reported on microgametogenesis of G. Laureleus (Desser \& Li 1984), G. aculeati (Jastrzebski 1989) and Calyptospora funduli (Hawkins et al. 1983b). The ultrastructural feature of microgamogony of $G$. subepithelialis resemble that of $G$. iroquoina, however, small microgamonts with few microgametes occurred, while $G$. subepithelialis developed large microgamonts producing large numbers of microgametes. To increase the surface area the microgamonts formed deep invaginations. Scholtyseck et al. (1972) considered this to be common among coccidian species which form large microgamonts with many 
microgametes and absent in species with small microgamonts. Invaginations of the surface area, however, also were observed in the small microgamonts of $G$. iroquoina (Paterson \& Desser 1981a). The microgametes of $G$. subepithelialis are biflagellate and possess additional microtubules not arranged in an axoneme, which appear to originate in the basal body region and extend posteriorly. These microtubuli were found in microgametes of numerous coccidian species (Paterson \& Desser 1981a, Chobotar \& Scholtyseck 1982).

Ultrastructural features of macrogametogenesis of piscine coccidia have been studied more extensively (Paterson \& Desser 1981b, Hawkins et al. 1983a, Desser \& Li 1984, Paperna et al. 1986). These studies revealed that macrogamonts of piscine coccidia often lack the wall forming bodies. In Goussia iroquoina (Paterson \& Desser 1981b) and G. laureleus (Desser \& Li 1984) electron-dense membrane-bound inclusions were described but were not observed to contribute to oocyst wall formation. Hawkins et al. (1983a) described 2 types of wall forming bodies from Calyptospora funduli macrogamonts, but did not observe the participation of these bodies in formation of the oocyst wall. Desser \& Li (1984) found their 'Type I' bodies to resemble the dense inclusions of $G$. iroquoina and $G$. laureleus macrogamonts. In $G$. subepithelialis macrogamonts numerous membrane-bound dense inclusions were arranged peripherally, but these structures also were not observed to be involved in the formation of the oocyst wall. In the macrogametes of specimens from South Bohemia dense bodies with electron-pale spaces have been found regularly. Blebs extending from the parasitophorous vacuole membrane have also been described from sexual stages of several fish coccidia (Paterson \& Desser 1981b, Hawkins et al. 1983b, Morrison \& Hawkins 1984, Jastrzebski 1989). Hitherto, vesicles in parasitophorous vacuoles have only been rarely found in coccidia from terrestrial hosts (Gajadhar \& Stockdale 1986, Daszak et al. 1989).

Acknowledgements. The study was performed using the equipment of the Electron Microscopic Unit of the Institute of Parasitology, Czechoslovak Academy of Sciences, Ceské Budejovice and the Elektronenmikroskopische Arbeitsgemeinschaft, School of Veterinary Medicine, Hannover. The investigations partly were performed during a stay of D.S. in Ceské Budéjovice, supported by a travelling grant of the CSAV. We thank Drs I. Dyková and J. Lom, Ceské Budějovice, for helpful suggestions.

Responsibie Subject Editor. Professor O. Kinne, Oldendorf Luhe, F.R. Germany

\section{LITERATURE CITED}

Chobotar, B., Scholtyseck, E. (1982). Ultrastructure. In: Long, P. L. (ed.) The biology of the Coccidia. Edward Arnold Press, London, p. 101-166

Daszak, P., Probert, A. J., Runham, N. W., Wilson, I. B. (1989) Ultrastructural observations on the gametocytic stages of the coccidium Tyzzeria chalcides Probert, Roberts \& WiIson, 1988 from the ocellated skink Chalcides ocellatus. J. Protozool. 36: 299-303

Desser, S. S., Li, L. (1984). Ultrastructural observations on the sexual stages and oocyst formation in Eimeria laureleus (Protozoa, Coccidia) from perch, Perca flavescens, from Lake Sasajewun, Ontario. Z. ParasitKde 70: 153-164

Gajadhar, A. A., Stockdale, P. H. G. (1986). Ultrastructural studies of microgametogenesis and macrogametogenesis of Eimeria truncata of the lesser snow goose. J. Protozool. 33: 345-351

Favikins, W. E., Solangi, M. A., Overstreet, R. M. (1983a). Ultrastructure of the macrogamont of Eimeria funduli, a coccidium parasitizing killifishes. J. Fish Dis. 6: 33-43

Hawkins, W. E., Solangi, M. A., Overstreet, R. M. (1983b). Ultrastructure of the microgamont and microgamete of Eimeria funduli, a coccidium parasitizing killifishes. J. Fish Dis. 6: 45-57

Jastrzebski, M. (1989). Ultrastructural study on the development of Goussia aculetati, a coccidium parasitizing the three-spined stickleback Gasterosteus aculeatus. Dis. aquat. Org. 6: 45-53

Marinček, M. (1973). Développement d'Eimenia subepithelialis (Sporozoa, Coccidia) - Parasite de la carpe. Acta protozool. 12: 166-174

Moroff, T., Fiebiger, J. (1905). Über Eimeria subepithelialis n. sp. Arch. Protistenk. 6: 166-174

Morrison, C., Hawkins, W. E. (1984). Coccidians in the liver and testis of the herring Clupea harengus L. Can. J. Zool. 62: $480-493$

Paperna, I., Landsberg, J. H., Feinstein, N. (1986). Ultrastructure of the macrogamont of Goussia cichlidarum Landsberg and Paperna, 1985, a coccidian parasite in the swimbladder of cichlid fish. Ann. Parasitol. Hum. Comp. 61: 511-520

Paterson, W. B., Desser, S. S. (1981a). An ultrastructural study of microgametogenesis and microgamete in Eimeria iroquoina Molnar and Fernando, 1974 in experimentally infected fathead minnows (Pimephales promelas, Cyprinidae). J. Parasit. $67 \cdot 314-324$

Paterson, W B., Desser, S. S. (1981b). Ultrastructure of macrogametogenesis, macrogametes and young oocyts of Eimeria iroquoina Molar and Fernando, 1974 in experimentally infected fathead minnows (Pimephales promelas, Cyprinidae). J. Parasit. 67 496-504.

Pellérdy, L., Molnár, K. (1968). Known and unknown eimerian parasites of fishes in Hungary. Folia Parasitol. (Prague) 15 $97-105$

Schäperclaus, W. (1943). Die Darmcoccidien, insbesondere die Knötchencoccidiose des Karpfens. Z. Fisch. 41 283-295

Scholtyseck, E., Mehlhorn, H., Hammond, D. M. (1972). Electron microscope studies of microgametogenesis in coccidia and related groups. Z. ParasitKde 38: 95-131

Ziesche, A. (1914). Bemerkungen zur Entwicklung von Eimeria subepithelialis. Zool. Anz. 44: 67-75

Manuscript first received: March 8, 1990

Revised version accepted: May 31, 1990 